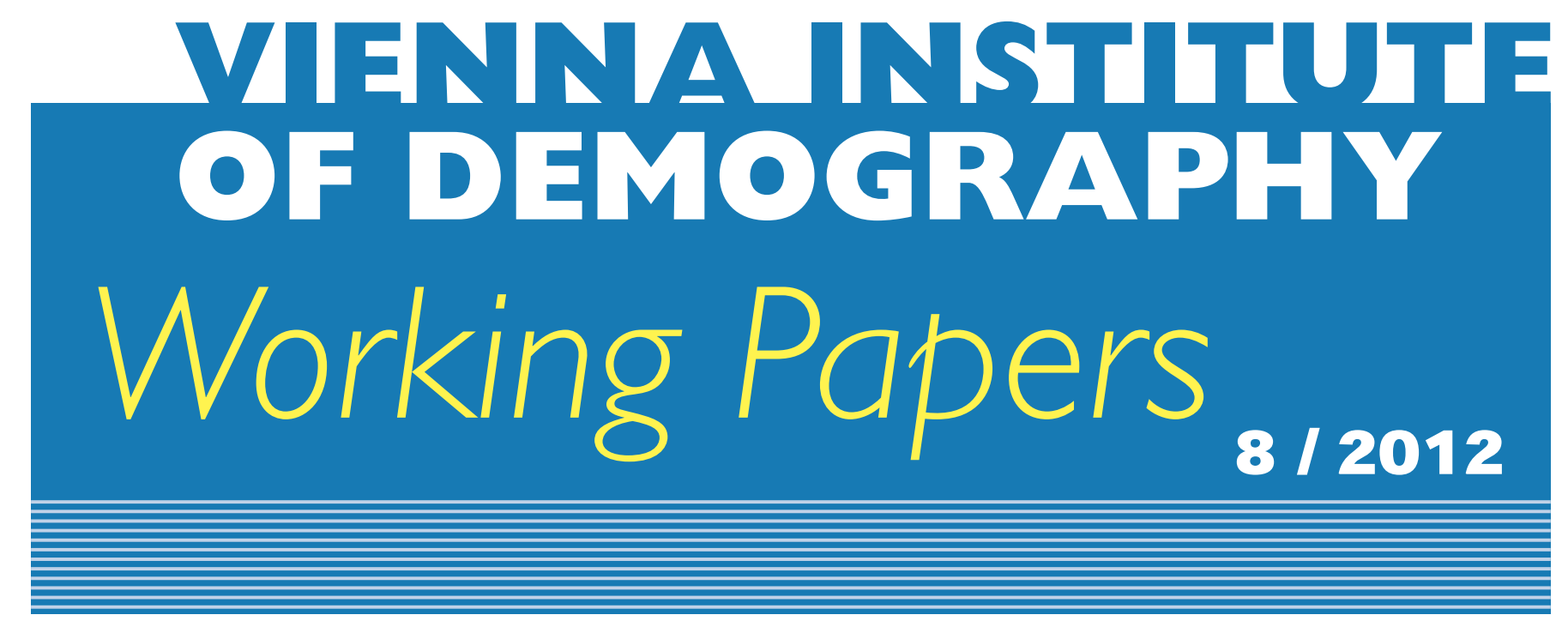

Isabella Buber, Ralina Panova and Jürgen Dorbritz

\title{
Fertility Intentions of Highly Educated Men and Women and the Rush Hour of Life
}

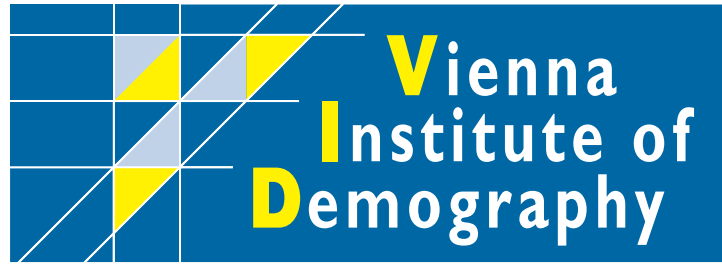

Vienna Institute of Demography Austrian Academy of Sciences

Wohllebengasse 12-14

A-1040 Vienna $\cdot$ Austria

E-Mail:vid@oeaw.ac.at

Website: www.oeaw.ac.at/vid 


\begin{abstract}
The life span between the mid-twenties and the late thirties is characterised by multiple demands. In recent years, the expression "rush hour of life" has been used to describe periods of time when conflicting demands are felt most acutely, in particular related to family formation and fertility. This is especially relevant for highly educated persons who often face later entrance into the labour market and postponement of family formation due to long educational involvement. We study fertility intentions of highly educated women and men, concentrating on 2,187 university degree holders aged 27 to 40 years in western Germany, Austria, the Netherlands, France and Norway. We attempt to operationalize the rush hour of life in a multivariate framework by taking into consideration different life domains (private, work) and their temporal dimension and relate them to family formation plans. The study reveals remarkably lower fertility intentions as well as substantial gender differences in Germany and Austria. Childbearing plans are most pronounced among university graduates around the age of thirty, thus in the prime time of their rush hour of life. What is associated with fertility intentions is not only the degree of institutionalisation but also the duration of the relationship. Moreover, the amount of working hours is related to childbearing plans.
\end{abstract}

\title{
Keywords
}

Rush hour of life, fertility intentions, family formation, highly educated, university graduates, Generations and Gender Survey

\section{Authors}

Isabella Buber (corresponding author) is researcher at the Wittgenstein Centre (IIASA, VID/ÖAW, WU), Vienna Institute of Demography/Austrian Academy of Sciences, Austria. Email: isabella.buber@oeaw.ac.at

Ralina Panova is researcher at the Federal Institute for Population Research (BIB), Germany. Email: ralina.panova@destatis.de

Jürgen Dorbritz is director of research at the Federal Institute for Population Research (BIB), Germany. Email: juergen.dorbritz@destatis.de

\section{Acknowledgements}

The authors would like to thank the participants of a colloquium at the Vienna Institute of Demography (VID), as well as Martin Bujard, Detlev Lück and Kerstin Ruckdeschel for their comments on an early version of the paper. Thanks to Robert Naderi, Lars Dommermuth, Trude Lappegard, Arnaud Regnier-Loilier, Michaela Potancokova and Kryštof Zeman for providing additional data and to Faith Ann Gibson and Werner Richter for language editing. This study was funded by the German Federal Ministry of the Interior under order number B1.11-1427/10/VV:2. 


\title{
Fertility Intentions of Highly Educated Men and Women and the Rush Hour of Life
}

\author{
Isabella Buber, Ralina Panova, and Jürgen Dorbritz
}

\section{Introduction}

During the last decades, childlessness has increased continuously across Europe (Frejka 2008). Although childlessness is not a new phenomenon historically, it has been gaining increasing significance in the demographic literature and socio-political discussion (Frejka and Sardon 2004; Konietzka and Kreyenfeld 2007). The rise in permanent childlessness is exceptionally pronounced in Germany and one of the reasons for low fertility in that country. Education-specific studies show that childlessness is a particularly widespread phenomenon among female university graduates (Dorbritz 2011). This applies to women in western Germany in particular, who in the past frequently found themselves faced with the choice between children or a career due to the low supply of child care facilities. If the educational elite of a nation are seen as the vanguard for social change (Lesthaeghe and Surkyn 1988), highly educated persons can be considered as pioneers of socio-economic change, which also includes fertility behaviour. In this respect, it is of interest to society to study the generative behaviour of highly educated women and men.

In the discussion about reasons for childlessness among highly educated persons, we increasingly encounter the term "rush hour of life" (Bertram 2007; Bertram and Bujard 2012). Demands from apparently conflicting life domains job/career and family/private are seen in context with generative behaviour and the pathway to childlessness. The objective of this study is to analyse the fertility intentions of highly educated women and men in the context of the "rush hour of life." First, we will operationalize the concept itself. Our research focuses on the concentration of biographical events and the particularly high time pressure in the phase of life between mid-twenties and late thirties. In particular, we examine associations between employment and relationship on the one hand and plans for starting a family on the other among highly educated persons in selected European countries. We analyse the extent to which different biographical and social circumstances are related with fertility intentions, taking into consideration possible gender-specific and country-specific differences. The study focuses on Germany and Austria as countries with high levels of childlessness. For an international comparison, France, the Netherlands and Norway were included as countries with comparable high levels of fertility and different institutional background regarding the reconciliation of family and work. The selection of the countries was based on different types of family policies (Gauthier 1996) and the availability of data from the Generations and Gender Survey (GGS). France was included in the analyses as a country classified as the pronatalist type. Norway represents the egalitarian family policy type and the Netherlands the time-oriented family policy type, while Germany and Austria are classified as the traditionalist family policy type. 


\section{Generative Behaviour, Childlessness and Education}

Germany and Austria are among the countries with the lowest fertility in Europe (Sobotka 2011), France, the United Kingdom and the Scandinavian countries are known for comparatively high fertility, the Netherlands currently lies in the upper field (TFR 2010: Germany: 1.39; Austria: 1.44; Netherlands: 1.79; Norway: 1.95; United Kingdom: 1.98; France: 2.00) (VID-IIASA 2012). Over the past four decades Europe has witnessed a rise in the average age at first birth (Bongaarts and Sobotka 2011), and rising educational enrolment accounts for a substantial part of fertility postponement (Ní Bhrolcháin and Beaujouan 2012). In most European countries the transition to motherhood currently takes place on average at age 28-29 (Kreyenfeld et al. 2010; Sobotka 2010). The relation between postponement of family formation and fertility differs. Whereas in France a high age at first birth is accompanied by a high number of children and low childlessness (Gerlach 2004; Köppen, Mazuy, and Toulemon 2007), in Germany the delay in motherhood is associated with a rise in childlessness and thus presumably has consequences for final family size (Kreyenfeld 2008).

Childlessness varies substantially between countries and regions (Frejka 2008; Konietzka and Kreyenfeld 2007) and amounts to 22 percent in West Germany for cohorts born 19641968 (Statistisches Bundesamt 2010) and to 18 percent in Austria for the 1965/66 cohorts (Sobotka 2011) as well as in the Netherlands for the 1965 birth cohort (Fokkema et al. 2008). With a share of 13 percent, France and Norway exhibit low levels of childlessness for the 1960s cohorts (Sobotka 2005; Toulemon, Pailhé, and Rossier 2008). Moreover, childlessness is low in former East German regions with a share of 11 percent for the 1964-1968 cohorts (Statistisches Bundesamt 2010), indicating considerable regional differences in Germany (Dorbritz 2005; Konietzka and Kreyenfeld 2007).

Throughout the 20th century, lower fertility is associated with higher education of women (Skirbekk 2008). Nevertheless, education-specific differences in fertility vary substantially within Europe. The negative educational gradient is particularly pronounced in countries where the institutional framework supports a relatively long absence of mothers from the labour force and where women perceive difficulties in reconciling family and work, such as in Germany, Austria and Switzerland (Merz and Liefbroer 2011; Sobotka 2011). In contrast, fertility differences by educational level are relatively small in France, the Netherlands and Norway (Davie and Mazuy 2010; Kravdal 2001; Lappegard 2002; Toulemon et al. 2008).

A positive correlation between educational level and childlessness is well documented for Germany (Duschek and Wirth 2005; Scharein and Unger 2005) as well as for a number of other European countries (Fokkema et al. 2008; Keizer, Dykstra, and Jansen 2008; Köppen et al. 2007; Lappegard 2000). In the birth cohorts cited above, among women holding a university degree childlessness amounts to 33 percent in western Germany, 30 percent in Austria and 29 percent in the Netherlands (Fokkema et al. 2008; Prskawetz et al. 2008; Statistisches Bundesamt 2010). Childlessness among academics is even higher; estimates for female professors in Germany and Austria range between 45 and 60 percent (Auferkorte-Michaelis et al. 2006; BMBF 2010; Buber, Berghammer, and Prskawetz 2011; Buchholz 2004; Metz-Göckel 2009). The share of childless university graduates is lower in France (18 percent), and Norway (19 percent) (Köppen et al. 2007). The comparatively 
low childlessness rate of Norwegian female university graduates is accompanied by high gender equality and high enrolment and employment rates of women, both ensured by the family policy guidelines in that country (Rønsen 2004).

Explanations for high childlessness among highly educated women focus mainly on difficulties in reconciling work and family roles (Dorbritz 2005; Fokkema et al. 2008; Lind 2008), the strong career orientation of female university graduates, the high opportunity costs (Liefbroer 2005) as well as the postponement of family formation due to the considerable time spent in education (Fokkema et al. 2008; Liefbroer and Corijn 1999). A stable career increases the likelihood of remaining childless among women, but increases the likelihood of entering fatherhood for men (Keizer et al. 2008), thus indicating distinctive pathways into childlessness among men and women. Apart from economic aspects, the private situation is certainly most important for family formation. Regarding the specific situation of highly qualified women, the lack of a suitable partner of a stable relationship is a central cause of childlessness in many countries of western and northern Europe (Dorbritz 2011; Keizer 2010; Köppen et al. 2007).

\section{The Concept of Life Course and the 'Rush Hour of Life'}

Fertility as a "purposive behaviour that is based on intentions, integrated into the life course" (Schoen et al. 1999: 799) and its realisation depends on specific framework conditions. Fertility intentions are complex and embedded in the specific social context (Dommermuth, Klobas, and Lappegard 2011; Schneider, Limmer, and Ruckdeschel 2002). The desire to have a child depends on the time frame (e.g. now, within three years, later) and might change over time according to the prevailing personal and social context (Schoen et al. 1999). Although the realisation of fertility intentions is influenced by various factors (Spéder and Kapitány 2009), we assume that child-timing intentions are predictors for subsequent family formation (Miller and Pasta 1995; Schoen et al. 1999) and the lack of them constitutes a relevant indicator for remaining childless.

As a theoretical framework for analysing fertility intentions in the rush hour of life, this paper is based on the sociological concept of the life course by Elder and Mayer (Elder 1977; Mayer 1990, 2003), in which we locate the rush-hour approach. According to the life-course perspective, individuals move through a sequence of age-graded events, situation and social roles (Elder 1977). The timing of live events, such as childbirth and transitions between different social settings, is specified by normative expectations and shaped by institutional constrains (Elder 1977; Mayer 2001, 2003). Individual life courses are closely linked to the dynamics of the social group to which they belonged (Mayer 2003). On the one hand institutional arrangements vary from society to society, creating cross-cultural differences in institutionalised pathways and life course patterns. On the other hand life course patterns vary across status groups within a given society (Elder 1977; Mayer 2003). A central aspect of the life course concept is the multidimensionality of the action patterns. Young adults are involved in "multiple lines of adult activity-of work and civil responsibilities, marriage and parenthood" (Elder 1977: 283). The individual life course develops in different life domains such as work and family and between these areas there are multiple interdependencies (Mayer 2003). The different life domains imply competing demands for the individual's limited time and energy resources 
(Elder 1977). In the part of life around the age of 30 years, under certain conditions in modern societies, different competing demands/events such as labour market entry, career establishment and consolidation, finding a suitable partner, cohabitation, marriage and starting a family concentrate in the so-called rush hour of life.

The current study builds on the concept of the rush hour of life to study the assumed concentration of biographical events around the age of 30 years among highly qualified persons in selected European countries and their association with childbearing intentions. Although a study by Bittman and Wajcman (2000) is regarded as the pioneering paper on the rush hour of life, the authors do not further elaborate on the expression "rush hour of life", but focus on gender-specific differences in the distribution of leisure time and the quality of leisure. The authors state that a high proportion of the population reported "feelings of being rushed" and mention that "there is mounting evidence that an increasing proportion [...] perceive their lives as rushed and feel that they do not have enough time to fit everything in" (Bittman and Wajcman 2000, p. 168). The expression "rush hour of life" has been coined to describe periods of time when multiple and conflicting demands are felt most pressing.

In recent years, the rush hour of life has been associated with the concentration of different phases of life and the de-standardisation of the life course (Bertram, Bujard, and Rösler 2011; Nimwegen, Esveldt, and Beets 2003). The expression "rush hour of life" is used to describe those periods in the mid-phase of life when multiple and conflicting demands are experienced as a real pressure. From a life-course perspective, Bovenberg (2008) uses a comparison with the four seasons and states that "the summer season in the modern life course is quite hot. The costs of living are high while time is scarce, as parents invest not only in their children but also in their careers. During this so-called rush hour of life, people may experience 'combination stress' (p. $608 \mathrm{ff})$. ."

According to Lothaller (2008) the rush hour of life is a new phenomenon that arose in the late 20th century, encompasses the time of life between the mid-twenties and later thirties and affects in particular more highly educated people who must simultaneously deal with the demands of work/career and family. Prolonged educational phases on the one hand and increased employment of women on the other hand, which is accompanied by an erosion of traditional tasks, are central to the phenomenon of the rush hour of life. Within a short time span of five to seven years, entrance into the labour market, career establishment and family formation take place — or "have to take place" - which makes up for a concentration of biographical events. According to the life course approach, we can interpret the rise in women's age at first birth and the increasing childlessness among highly qualified women as consequences of the time pressure that dominates during the rush hour of life. With the rising number of more highly educated persons, the group of those going through the rush hour of life becomes ever larger, with effects spreading from the individual level to the social level (Lothaller 2008).

The Seventh German Family Report (BMFSFJ 2006) explicitly addresses the rush hour of life. It is speculated that this phenomenon is particularly pronounced in Germany, because the German educational system, especially in academic professions, does not show much differentiation (access to professional life is generally defined by one's highest completed level of education). Other places, in particular the northern European and Anglo-Saxon 
countries, offer a variety of educational qualifications that can be acquired at various times of life, thus allowing a flexible arrangement of life plans over the life course (BMFSFJ 2006). Moreover, Peuckert (2008) observed a shrinking time frame for parenthood in Germany, as the duration of the fertile years actually used has decreased significantly. In the Scandinavian countries, France and the Netherlands life decisions have also been shifted to higher ages, but they are not concentrated to a time period as short as in Germany. It is speculated that the time pressure for highly educated German adults in the age span between 27 and 35 years is higher than in other countries. Whereas time stress and "time crunch" has been addressed in the literature (Hamermesh and Lee 2007; Hochschild 1997), less attention has been paid towards the link between the compression of life course events and family formation.

\section{Hypotheses}

Based on Kreyenfeld and Konietzka (2007), we assume that from the life-course perspective childlessness is an expression of complex life-course constellations and the result of a succession of biographical decisions related to various areas of life, primarily education, working life and personal ways of life. Vertical differentiations according to educational categories are crucial to the chronological arrangement of life courses. They influence primarily the early fertility decisions and therefore the time of first birth. A higher educational level involves longer educational enrolment and thus a later entry into working life. We assume that biographical events - completion of education, labour market entrance, first career steps and the search for a suitable partner, or the consolidation of one's relationship - concentrate around age 30 among highly qualified men and women, which affects preferential fertility decisions. Against this background, our central hypothesis is that the concentration of biographical events around age 30 has negative effects on fertility intentions and generative behaviour and can be seen as a pathway to childlessness. We operationalize this step-by-step process as follows:

Hypothesis 1: We assume that the lack of a partner as well as the degree of institutionalisation of a relationship, including in particular the lack of a cohabiting partner, are essential for fertility intentions. In particular, we assume that the level of consolidation of a relationship - measured by the degree of institutionalisation, the duration and the quality of the relationship - is associated with fertility intentions: the higher the consolidation of a relationship, the higher fertility intentions will be.

Hypothesis 2: We assume an association between employment conditions and fertility intentions. More precisely, we hypothesise that comparably low as well as extremely high workloads are associated with low fertility intentions, conveying economic problems and precarious employment conditions on the one hand, and limited time resources for private life on the other. Moreover, we hypothesise that uncertain employment conditions such as temporary work contracts and self-employment are associated with low fertility intentions.

Hypothesis 3: A short duration of the current job indicates the need for job consolidation and is negatively associated with fertility intentions.

Regarding the societal level we formulate the following two hypotheses: 
Hypothesis 4: In countries with traditional role models and a low degree of institutionalisation of child care, fertility intentions of female university graduates are less pronounced.

Hypothesis 5: In countries with traditional role models we anticipate that highly educated women desire to have children less often than highly educated men.

\section{Data and Methods}

The current study is based on the first wave of the "Generations and Gender Survey" (GGS) in western Germany, Austria, France, the Netherlands and Norway as well as on an additional sample of female researchers in Austria (for further information we refer to Buber 2010). In Germany, differences in fertility are persisting between former East and West Germany (Goldstein and Kreyenfeld 2011; Goldstein et al. 2010). Due to the small sample size, we excluded eastern Germany in the current study. In the following, we therefore refer to western German provinces only when mentioning "Germany". We focus on highly educated men and women, whom we define as persons holding ISCED 5a/ISCED 6 degrees, i.e. having studied at a university or at a university of applied sciences. In the following, we will refer to these persons also as "university graduates" or "the highly educated", thus using the terms synonymously. We do not include persons with tertiary education with a vocation-specific qualification (ISCED 5B), since this group's vocational biography (e.g. apprenticeship, trade examination, master craftsman's examination) is generally different from those who completed higher secondary education and then studied at university.

The study focuses on Germany and Austria, two countries with high childlessness among highly educated persons, and with very similar social, political and economic structures. In addition, France, the Netherlands and Norway were included as countries with both higher fertility rates and different family policy circumstances, thus allowing a European comparison. The selection of the countries was based on different types of family policies (Gauthier 1996) and also the availability of data from the Generations and Gender Survey (GGS). Data were pooled and analyses conducted for the entire sample as well as separately for women and for men in order to identify possible gender-specific differences (Widmer and Ritschard 2009).

In addition to fertility intentions, birth and partner histories, the GGS includes detailed information on the current employment situation and on education. Therefore, this dataset enables us to analyse fertility intentions in a multivariate context, taking into consideration various dimensions of the rush hour of life. Since questions on fertility intentions were not posed to persons with same-sex partners, we were unable to take this group into consideration. Moreover, we excluded those who were unable to have biological children, who had missing data on fertility intentions or who were expecting a child at the time of the interview. The final sample comprises 2,187 highly educated women and men aged 27 to 40 years, holding ISCED 5a or ISCED 6 degree and with valid responses to the question whether they intended to have a child within the next three years (Table 1). We distinguished by parities (Bulatao 1981; Yamaguchi and Ferguson 1995) and concentrated 
on childless persons as well as on parents of one child. Nevertheless, analyses were carried out for all highly educated respondents regardless of their parity and are included in the Appendix.

Of the 2,187 university graduates, 61 percent were female and 39 percent male. This reflects the sample structure of the GGS (Vikat et al. 2007), which surveyed more women than men in all countries, since research in demography focuses mainly on women. The increasing significance of men in demographic literature was taken into account to the extent that a sufficient number of men were surveyed in all countries. Therefore the GGS allows gender-specific analyses of fertility intentions in Europe.

Table 1. Sample by country and gender

\begin{tabular}{|c|c|c|c|}
\hline & Men & Women & Total \\
\hline Germany & 113 & 206 & 319 \\
\hline Austria & 133 & 269 & 402 \\
\hline Austrian female researchers & 0 & 161 & 161 \\
\hline France & 241 & 371 & 612 \\
\hline Netherlands & 126 & 140 & 266 \\
\hline Norway & 230 & 197 & 427 \\
\hline Total & 843 & 1,344 & 2,187 \\
\hline
\end{tabular}

Data source: GGS

The central variable of this study is the desire to have a child within the next three years. First analyses (results not shown here) revealed that the current relationship and vocational situation are to a greater extent associated with fertility intentions in the near future than with general fertility intentions, i.e. the desire to have children at all. Moreover, from a theoretical point of view, the shorter time-span of three years is better suited to the concept of the rush hour and conflicting demands

We restrict ourselves to few descriptive results and focus on multivariate analyses in order to handle problems in the representativeness of the data-in particular of the German dataset (Kreyenfeld et al. 2011; Sauer, Ruckdeschel, and Naderi 2012). The average age of respondents is 34 years, German females were somewhat older (35 years) and female researchers in Austria somewhat younger (32 years). The proportion of highly educated persons wishing to have a child within the next three years ranges from 39 percent in Germany and Norway to 51 percent in Austria. Childless persons and parents of one child more often planned a child in the near future (55 and 63 percent respectively) than parents of two or more children (19 and 8 percent).

Our study is, to our knowledge, the first that attempts to operationalize the concept of the rush hour of life in the context of fertility and family formation. Therefore, indicators for relationship and employment are related to fertility intentions. Moreover, we add a time component, since the central idea of the rush hour of life is the temporal aspect and the concentration of decisions and biographical events within a short time span. 
It takes a certain amount of time before a relationship becomes consolidated, until a couple knows each other well and thinks about having children together. On the job, too, it usually takes a certain amount of vocational adjustment and practice before one becomes established within the company. Since university graduates are confronted with increased vocational uncertainties (Klammer 2010) relevant information from the GGS were used, such as type of contract or satisfaction with job security.

In a multivariate framework probit regressions are carried out. The dichotomous explanatory variable is the desire to have a child within the next three years. In a first step, we run a basic model including age, country, gender, partner status, relationship quality, and employment status as explanatory variables. In a second step, we include - in an extended model - duration of partnership, duration of current job and the current workload (measured in hours worked). Moreover, we account for type of contract and satisfaction with job security. Unfortunately, not all variables are available for the five countries. The Dutch GGS is based on the "Netherlands Kinship Panel Study" (NKPS) and deviates from the international GGS questionnaire (Dykstra et al. 2005). For instance, the beginning of the current relationship and of the current employment are not coded, and consequently the duration of the relationship and employment cannot be calculated. Data are also lacking on the actual hours worked as the Dutch data only differentiate between full-time and parttime work. Hence, the Netherlands had to be excluded in the extended model. In the basic model, however, highly educated Dutch were included to place the fertility intentions of university graduates in the Netherlands in the European context.

Regression analyses are calculated for the total sample, as well as for men and women separately to be able to identify possible gender-specific differences. We distinguish by parities and concentrate on childless respondents to identify possible pathways to permanent childlessness among highly educated people. Moreover, we compare childless persons to individuals with one child. Analyses for all university graduates regardless of their parity are provided in the Appendix.

\section{Results}

In the basic model, including childless in Germany, Austria, female Austrian researchers, France, the Netherlands and Norway, age is-as expected-significantly associated with fertility intentions. These are highest among university graduates in their early thirties, whereas those under the age of 30 and between 35 and 40 years less often intend to have a child (Table 2). Differences by age groups are more pronounced among women than among men.

Country-specific differences vary by gender. Taking Germany as the reference group, childbearing plans of childless persons do not significantly differ between Germany, Austria and the Netherlands but are significantly higher among French and Norwegian women. France and Norway represent countries with less traditional role models and a higher degree of institutionalisation of child care. Therefore, our results support Hypothesis 4, assuming that in countries with traditional role models and a low degree of institutionalisation of child care, fertility intentions of female university graduates are less pronounced. Among childless men, Germans lie in the middle range, childbearing plans 
being lowest among Dutch men. The gender differences in Norway (comparably high among women and comparably low among men) are in line with research by Kravdal and Rindfuss (2008) who found an increasing level of childlessness among highly educated men in Norway.

Table 2. Estimated coefficients from probit regressions for the desire to have a child within the next three years; basic model

\begin{tabular}{|c|c|c|c|c|c|c|}
\hline & \multicolumn{3}{|c|}{ Childless university graduates } & \multicolumn{3}{|c|}{$\begin{array}{c}\text { University graduates with one } \\
\text { child }\end{array}$} \\
\hline & All & Women & Men & All & Women & Men \\
\hline Age & & & & & & \\
\hline $27-29$ & $-0.36 * * *$ & $-0.36^{* *}$ & $-0.40 *$ & 0.06 & 0.21 & -0.36 \\
\hline $30-34^{\mathrm{a}}$ & 0 & 0 & 0 & 0 & 0 & 0 \\
\hline $35-40$ & $-0.34 * * *$ & $-0.48 * * *$ & -0.21 & $-0.75 * * *$ & $-0.79 * * *$ & $-0.74 * *$ \\
\hline Country & & & & & & \\
\hline Germany $^{\text {a }}$ & 0 & 0 & 0 & 0 & 0 & 0 \\
\hline Austria & 0.15 & 0.24 & 0.27 & 0.10 & 0.10 & 0.23 \\
\hline Austrian female researchers & -0.22 & 0.03 & & 0.23 & 0.20 & \\
\hline France & $0.47 * *$ & $0.77 * * *$ & 0.20 & 0.34 & 0.19 & $0.90 *$ \\
\hline Netherlands & $-0.33^{*}$ & 0.12 & $-0.73 * *$ & $1.05 * *$ & $1.33 * *$ & $1.03+$ \\
\hline Norway & 0.16 & $0.78^{* *}$ & -0.32 & $0.61^{*}$ & $0.83^{*}$ & $0.74+$ \\
\hline Gender & & & & & & \\
\hline Male $^{\mathrm{a}}$ & 0 & & & 0 & & \\
\hline Female & 0.10 & & & 0.01 & & \\
\hline Partner status & & & & & & \\
\hline Married & 0.16 & 0.28 & 0.07 & 0.18 & 0.15 & 0.36 \\
\hline Cohabiting $^{\mathrm{a}}$ & 0 & 0 & 0 & 0 & 0 & 0 \\
\hline Living apart together (LAT) & $-0.59 * * *$ & $-0.61 * * *$ & $-0.58 * *$ & $-0.72 *$ & -0.52 & -1.35 \\
\hline No partner & $-1.00 * * *$ & $-1.01 * * *$ & $-0.96 * * *$ & -0.30 & -0.14 & -1.18 \\
\hline $\begin{array}{l}\text { Relationship quality } \\
\text { (Very) good quality }\end{array}$ & 0 & 0 & 0 & 0 & 0 & 0 \\
\hline (Relatively) poor quality & -0.14 & -0.14 & -0.14 & -0.06 & -0.11 & -0.08 \\
\hline Employment status & & & & & & \\
\hline Full time $^{\mathrm{a}}$ & 0 & 0 & 0 & 0 & 0 & 0 \\
\hline Part time & -0.12 & -0.04 & -0.32 & 0.13 & 0.16 & 0.80 \\
\hline Not employed & -0.05 & -0.12 & 0.22 & $0.46^{*}$ & $0.56^{*}$ & -0.26 \\
\hline Constant & $0.69 * * *$ & $0.54 *$ & $0.88 * * *$ & 0.21 & 0.22 & -0.03 \\
\hline Pseudo $\mathrm{R}^{2}$ & 0.12 & 0.14 & 0.13 & 0.13 & 0.14 & 0.16 \\
\hline $\mathrm{N}$ & 1,072 & 633 & 439 & 397 & 260 & 137 \\
\hline
\end{tabular}

Significance levels: $+\mathrm{p}<0.10 ; * \mathrm{p}<0.05 ; * * \mathrm{p}<0.01 ; * * * \mathrm{p}<0.001$.

${ }^{a}$ Reference category.

Remark: See Table A1 in the Appendix for the distribution of the variables.

Source: GGS Wave 1.

In the basic model we find no gender difference in childbearing intentions for men and women. But country-specific analyses reveal that this is due to effects of opposite size. In Germany and Austria childless highly educated women desire a child considerably less often than highly qualified men (Table 3). The situation is the opposite in the Netherlands and in Norway. In Germany and Austria traditional role models are still prevailing. Thus 
our results support Hypothesis 5, anticipating that in countries with traditional role models highly educated women less often desire to have children compared to highly educated men.

Table 3. Estimated coefficients for gender differences for the desire to have a child within the next three years. by country

\begin{tabular}{l|cc} 
& Childless university graduates & University graduated with one child \\
\hline All countries & 0.10 & 0.01 \\
Germany & $-0.49+$ & -0.25 \\
Austria & $-0.42^{*}$ & $-1.29^{*}$ \\
France & 0.19 & -0.17 \\
Netherlands & $0.57^{*}$ & \\
Norway & $0.90^{* * *}$ & 1.08 \\
\hline
\end{tabular}

Note 1: Reference category is men. Controlled for age, relationship, relationship quality and employment status, see Table 2.

Note 2: The Dutch sample of university graduates with one child includes only 33 records and allows no detailed analyses.

The degree of institutionalisation of a relationship is positively related to fertility intentions, confirming our Hypothesis 1. Married and cohabiting persons desire a child more often than persons living apart together or without a partner. The estimated coefficient for those reporting relatively poor relationship quality is negative but fails to reach statistical significance. The results for the current employment status reveal no significant differences between part-time and full-time employed and higher childbearing intentions among non-employed respondents in the sample of childless university graduates. Unfortunately, the group of non-employed persons is very heterogeneous, a further distinction in subgroups yielded no significant results and we refer to the extended model for more elaborated results.

In the sample of highly educated respondents with one child, age is significantly associated with fertility intentions and those aged 35-40 years less often intended a second child compared to those in their early thirties. We find no difference between Austrian, German and French women. Once university graduates have one child, the intention to have a second is comparable in these countries. By contrast, Dutch and Norwegian highly educated women more often intended a sibling for their first child. Again, gender-specific differences prevail but are less pronounced than among childless respondents, which might be partly due to the comparably small size of the sample of persons with parity one. In contrast to childless people, employment status is significantly associated with fertility intentions of parents with one child. Further analyses revealed that this is mainly due to homemakers and women on parental leave.

As mentioned earlier, we concentrate on childless persons and on parents of one child. Analyses comprising all university graduates, i.e. also those with two or more children indicate that highly educated respondents plan to have a first and a second child but do not intend families with three or more children (Appendix Table A2). 
In our extended model we take into consideration temporal aspects such as duration of partnership and duration of current job as well as the amount of working hours (Table 4, Appendix Table A4). As mentioned earlier, we exclude the Netherlands due to nonavailability of data and thus limit ourselves to Germany, Austria, France and Norway. Results for age and country are comparable to the basic model. For combining partner status and duration of partnership, various classifications and sub-group were modelled, taking into consideration size of subgroups and significance of results. For the final model presented here, the cutting point is three years for cohabitation and marriage, and two years for living-apart-together (LAT) partnerships. The combination of partner status and duration of partnership reveals diverging results.

Contrary to our Hypothesis 1 (referring to the consolidation of partnership), there is a negative correlation between duration of cohabitation and fertility intentions. Hence, highly qualified persons cohabitating less than three years desire a child more often than those who have already been cohabitating with their current partner for three years or longer. This finding contradicts our hypothesis regarding the degree of partnership consolidation and might be explained by a selection process. Highly educated persons cohabiting for a longer period of time who are still childless and have not married after a while might be a selected group that is less family-orientated. Duration of marriage had no effect on fertility intentions. For highly educated persons living apart together with their partner, duration mattered for family formation intentions: those in a longer LAT relationship (two years and longer) intend to have a child more often than those in a relatively short LAT relationship (less than two years). It is particularly interesting that in the female sample the estimated coefficient for short LAT partnership is statistically not significantly different from those without a partner (results not shown here), whereas in the childless male sample we find statistically significant results. We might conclude that in terms of fertility intentions, highly qualified childless women in a short LAT partnership are more similar to those without a partner than to those in a longer LAT relationship. By contrast, among childless men fertility intentions are already more pronounced in the presence of a short LAT partnership.

In the expanded model we take into consideration the hours actually worked, in order to better examine the vocational time burden during the rush hour of life. According to our calculations, full-time employment in the range of 35 to 40 hours, full-time employment with a modest amount of overtime (i.e. between 41 and 50 hours) and part-time employment in the range of 30 to 34 hours are associated with fertility intentions in a more or less similar way. Part-time work comprising less than 30 hours per week is significantly negatively related with the fertility intentions of highly educated childless men and women. Childless university graduates who have a part-time job with less than 30 hours per week are presumably not yet established on the labour market and possibly also perceive financial restrictions, so they do not favour family formation in the near future. Our results on part-time work support Hypothesis 2, in the way that relatively few working hours are associated with low fertility intentions, conveying a still precarious position in the labour market and possibly economic problems. 
Table 4. Estimated regression coefficients for the desire to have a child within the next three years; extended model

\begin{tabular}{|c|c|c|c|c|c|c|}
\hline & \multicolumn{3}{|c|}{ Childless university graduates } & \multicolumn{3}{|c|}{$\begin{array}{l}\text { University graduates with one } \\
\text { child }\end{array}$} \\
\hline & All & Women & Men & All & Women & Men \\
\hline Age & & & & & & \\
\hline $27-29$ & $-0.34 * *$ & $-0.39 * *$ & -0.29 & 0.15 & 0.19 & -0.15 \\
\hline $30-34^{\mathrm{a}}$ & 0 & 0 & 0 & 0 & 0 & 0 \\
\hline $35-40$ & $-0.36^{* *}$ & $-0.52 * * *$ & -0.18 & $-0.71 * * *$ & $-0.69 * * *$ & $-0.72 *$ \\
\hline Country & & & & & & \\
\hline Germany $^{\text {a }}$ & 0 & 0 & 0 & 0 & 0 & 0 \\
\hline Austria & 0.17 & 0.23 & 0.36 & 0.12 & 0.22 & -0.26 \\
\hline Austrian female researchers & -0.16 & 0.04 & & 0.35 & 0.41 & \\
\hline France & $0.48 * *$ & $0.76^{* * *}$ & 0.29 & 0.36 & 0.40 & 0.58 \\
\hline Norway & 0.17 & $0.76^{* *}$ & -0.26 & $0.72 * *$ & $0.94 *$ & 0.51 \\
\hline Gender & & & & & & \\
\hline Male $^{a}$ & 0 & & & 0 & & \\
\hline Female & 0.00 & & & 0.02 & & \\
\hline Partner status & & & & & & \\
\hline Married less than 3 years & $(0.94 *)$ & & 0.88 & 0.40 & 0.98 & -0.02 \\
\hline Married 3 years and longer & 0.22 & 0.21 & 0.38 & 0.23 & 0.19 & 0.23 \\
\hline Cohabiting less than 3 years & $0.36^{*}$ & 0.24 & $0.62+$ & -0.06 & 0.15 & -0.51 \\
\hline Cohabiting 3 years and longer & 0 & 0 & 0 & 0 & 0 & 0 \\
\hline LAT less than 2 years & $-0.59 * * *$ & $-0.70 * *$ & -0.37 & -0.55 & -0.08 & \\
\hline LAT 2 years and longer & $-0.41 *$ & $-0.46^{*}$ & -0.33 & & & \\
\hline No partner ${ }^{\mathrm{a}}$ & $-0.91 * * *$ & $-0.98 * * *$ & $-0.76^{* *}$ & -0.30 & -0.02 & $-1.46+$ \\
\hline Partner quality & & & & & & \\
\hline (Relatively) poor quality & -0.17 & -0.17 & -0.20 & -0.03 & 0.04 & -0.14 \\
\hline (Very) good quality ${ }^{\mathrm{a}}$ & 0 & 0 & 0 & 0 & 0 & 0 \\
\hline Working hours & & & & & & \\
\hline Less than 30 hours & $-0.50 * *$ & $-0.42 *$ & $-0.64+$ & 0.20 & 0.27 & \\
\hline 30-34 hours & 0.08 & 0.10 & $(0.64)$ & 0.00 & 0.01 & \\
\hline $35-40$ hours $^{\mathrm{a}}$ & 0 & 0 & 0 & 0 & 0 & 0 \\
\hline 41-50 hours & -0.01 & -0.03 & 0.03 & 0.22 & -0.22 & $0.56+$ \\
\hline More than 50 hours & -0.09 & $-0.50 *$ & 0.39 & 0.08 & -0.10 & 0.21 \\
\hline Not employed & -0.03 & -0.09 & 0.32 & $0.52 *$ & $0.54+$ & 0.48 \\
\hline Duration of current job & & & & & & \\
\hline Less than 1 year & -0.14 & -0.11 & -0.12 & -0.10 & 0.06 & -0.01 \\
\hline $1-3$ years & -0.05 & -0.03 & 0.01 & -0.07 & -0.04 & 0.24 \\
\hline 4 years and longer ${ }^{\mathrm{a}}$ & 0 & 0 & 0 & 0 & 0 & 0 \\
\hline Constant & $0.69 * * *$ & $0.62 *$ & $0.51+$ & 0.08 & -0.04 & 0.13 \\
\hline Pseudo R ${ }^{2}$ & 0.13 & 0.16 & 0.14 & 0.10 & 0.11 & 0.16 \\
\hline $\mathrm{N}$ & 889 & 532 & 349 & 347 & 227 & 114 \\
\hline
\end{tabular}

Significance levels: $+\mathrm{p}<0.10 ; * \mathrm{p}<0.05 ; * * \mathrm{p}<0.01 ; * * * \mathrm{p}<0.001$.

${ }^{a}$ Reference category.

Remark 1: See Table A3 in the Appendix for the distribution of the variables.

Remark 2: Numbers in parentheses indicate small size of subcategory (i.e. 1-2 percent).

Source: GGS Wave 1 
Extensive working hours (i.e. more than 50 hours per week) are also associated with significantly low fertility intentions among women, but among childless men, by contrast, tendentially with higher fertility intentions, although this is not statistically significant. Our results indicate that for female university graduates who work 50 or more hours per week, family and work are particularly difficult to combine, whereas childless men with such high workloads might rather see economic advantages in extended workloads as this makes family formation easier to finance. Thus, our Hypothesis 2, assuming negative association between extended workload and fertility intentions due to restricted time resources, is supported only for highly educated women, not for men.

The estimated coefficient for short duration of the current job is not significantly associated with fertility intentions and Hypothesis 3, assuming that a short duration of the current job indicates the need for job consolidation and is negatively associated with fertility intentions, is not confirmed.

In the sample of highly educated respondents with one child, the association between working hours and fertility intentions is different. On the one hand, we no longer find a negative association between part-time work and fertility intentions, on the other there is a significantly higher intention of non-employed mothers with one child. Further analyses revealed that this is mainly due to homemakers and women on parental leave.

Table 5. Estimated coefficient for type of contract, by countries

\begin{tabular}{l|ccc} 
& \multicolumn{3}{|c}{ Childless university graduates } \\
\hline & Permanent & Temporary & Self-employed \\
& contract & -0.51 & -0.44 \\
contract & -0.34 \\
Austria & 0 & 0.13 & -1.24 \\
Austrian female researchers & 0 & 0.27 & $0.75+$ \\
France & 0 & 0.10 & 0.31 \\
Norway & 0 & -0.54 & \\
\hline
\end{tabular}

Note: Controlled by age, gender, country, partner status, partner quality, employment, duration of current job, see Table 4

The detailed job-related GGS data allow analyses by type of contract, distinguishing between permanent contract, temporary or limited contract for employees on the one hand, and self-employment on the other hand. Country-specific analyses reveal negative coefficients for those holding a temporary contract in Germany and Norway, but results are not statistically significant (Table 5). Moreover, self-employment is associated with lower fertility intentions in Germany and Austria, and with higher ones in France and Norway, but results are statistically significant only for France. Therefore, our results do not allow conclusions regarding the association between type of contract and fertility intentions. Hypothesis 2, assuming that uncertain employment conditions like temporary work contracts and self-employment are associated with low fertility intentions, has to be rejected failing statistical significance. Further analyses reveal that satisfaction with job security tends to increase the fertility intentions, but results are statistically significant only for Germany (results not shown here). 


\section{Discussion}

The objective of this article is to study fertility intentions among highly qualified women and men across Europe. Our considerations are based on the assumption that long educational involvement among the highly qualified leads to a later entry into working life and thus to a postponement of family formation. This leads to a concentration of biographical events around the age of thirty (graduation, start of working life, first career steps, consolidation of partnership, eventually marriage, family formation), the so-called "rush hour of life". The central thesis is that this time pressure has a negative effect on fertility intentions and might constitute a pathway to childlessness.

The term "rush hour of life" has recently been used for the concentration of different domains in the life course between one's mid-twenties and late thirties and has been related to family formation and fertility of more highly educated persons (Bertram 2007; Bertram et al. 2011). In this study we attempt to operationalize this concept by taking into consideration different life domains (private, work) and their temporal dimension, relating them to family formation plans. At the individual level, the multidimensional aspect of the rush hour of life was operationalized by including demographic characteristics such as age and partner status, and employment situation, combined with temporal aspects like duration of relationship and duration of current job. Age is significantly associated with fertility intentions. According to our results, these are most pronounced among university graduates around the age of thirty, thus in the prime time of the rush hour of life, whereas both younger and older highly educated persons less often intended a child in the near future. The steep decrease in intentions for the age-group of 35 to 40 years might also indicate a selection process or an adaptation to a childless personal lifestyle.

Analyses and explanations focus on Germany and Austria, two countries with low fertility and high childlessness in particular among female university graduates. For a European comparison, France, the Netherlands and Norway were chosen as countries with different government family policy regimes (Gauthier 1996). The results indicate an exceptional situation in Germany and Austria where childless highly educated women intend to have a child in the near future significantly less often than in France and Norway. In addition, we find considerable gender-specific differences in the two German-speaking countries with highly qualified women less often planning to have children compared to their male peers. This might be due to the family policy concepts pursued in the past. Monetary child support schemes were accompanied by a lack of structural policy for expanding public child care, enforcing the widespread and strongly normatively grounded "homemaker/breadwinner" model (Esping-Anderson 1990). Moreover, traditional gender roles are still prevailing. Typically women take maternal leave and only return to workoften part-time - when the child has reached the age of three. This societal ideal constitutes a conflict for highly qualified women who invested a great amount of time and money in their education, confronting them with problems in combining family and work or even with the decision of either work or parenthood. Highly educated women respond to the prevailing traditional gender role assignment with reduced fertility intentions, which might foreshadow the pathway to childlessness.

Apart from availability and affordability, cultural norms also influence the demands for child care services. Child care and motherhood are still sensitive issues. In most countries, 
attitudes vary according to the age of the child. Belgium and France are the only countries where child care services seem to be generally accepted. In Austria and Germany the attitude is that children should not attend child care facilities until they are at least 2 or even 3 years old. In the Netherlands it is widely accepted that mothers work part-time and make part-time use of child care facilities, but a full-time use is much less accepted, even for older children. In Norway, where the use of child care facilities for children above one year is generally accepted, there seems to be an informal norm that children should not spend too many hours in child care (Plantenga and Remery 2009). From the life course perspective, the labour participation of Norwegian women may be "as natural" just as implicit as child-raising (Lappegard 2000, p. 16).

The relationship situation and a suitable partner are crucial for fertility intentions. Married and cohabitating persons desire a child more often than persons in a living-apart-together relationship or persons without a partner. Not only the degree of institutionalisation but also the duration of a relationship is associated with childbearing plans, with genderspecific differences. We found that in terms of fertility intentions, highly qualified women in short LAT partnerships are more similar to those without a partner than to those in a longer LAT partnership. By contrast, fertility intentions among childless men are already more pronounced in the presence of a short LAT partnership. In the view of increasing LAT partnerships among highly educated people in times of high job mobility (Schneider et al. 2002), this result is relevant for future studies on highly educated men and women.

In the rush hour of life, the amount of working hours is related to childbearing plans. Parttime employment for less than 30 hours is negatively associated with family formation plans of childless persons, which presumably indicates economic restrictions and a not yet successful integration in the labour market. The association between great time burden and family formation plans is gender-specific. Lower intentions among women indicate difficulties in reconciling family and time-intensive work, but might also point towards strong work orientation, and possibly reduced family orientation, among childless highly educated women working more than 50 hours per week. Among childless men, extensive overtime hours tend to be related with higher family formation plans. After a recent job change, family formation tends to be of lower priority for men, who might wish to first consolidate themselves in their new vocational position, i.e. to gain a foothold at the new workplace and adapt to their new responsibilities, before starting or enlarging a family.

According to our country-specific analyses, temporary contracts but involve a postponement of parenthood in Germany and Norway, and furthermore self-employed persons in Germany and Austria tend to plan children less often than employees with permanent contract - as opposed to France, where self-employed people intend to have children significantly more often. Based on the available data, we cannot explain if this is due to country-specific economic and legal situations of self-employed, to a selection process of persons with certain characteristics being more likely to start or take over a company or to other reasons. Our results on temporary contract and satisfaction with job security confirm that especially in Germany a stable and long-term vocational perspective is important for family formation plans. The relevance of insecure employment conditions among young adults in Germany corresponds to the dominant idea of a "sequential life plan" (Peuckert 2008, p. 126), according to which the family phase should only begin after completion of education, a few years of work experience and therefore the establishment of 
a steady, secure financial and career-related basis. Based on the German Socio-Economic Panel, Kreyenfeld (2010) investigated whether uncertainties in female employment careers result in a postponement of family formation and found differences by educational levels. More highly educated women postpone parenthood when subject to employment uncertainties, whereas those with low educational levels often become mothers. Due to sample size, we are not able to study the group of highly educated unemployed persons, however.

In a comparison between French and German women, Fagnani (2002) concludes that differences between state policies per se should not be overestimated in explaining the persistent fertility gap between the two countries. She underlines the strong differences in women's attitudes towards child care outside of the home. Further research showed that being a parent has strong negative earning effects on women in Germany (Trappe and Rosenfeld 2000). Against the institutional but also the cultural background, an increasing number of women, often highly qualified ones, give priority to their job and career, reducing their number of children or remaining childless.

Our study has several limitations. First, we do not have any information whether individuals in our sample actually feel rushed. Surveys like the German Socioeconomic Panel (SOEP) 2002, the first wave of the Australian Household, Income and Labour Dynamics (HILDA) or the U.S. Panel Study of Income Dynamics (PSID) addressed the feeling of being rushed (Hamermesh and Lee 2007), but these data do not allow profound analyses of family formation. Second, the samples for single countries are rather small. Third, the couple perspective is important for fertility decisions (Jansen and Liefbroer 2006; Testa 2012; Testa, Cavalli, and Rosina 2012; Thomson and Hoem 1998). Although the data include information on the partners, relevant aspects such as partner's working hours are not captured. Moreover, the question arises if the rush hour of life is a choice or a constraint and whether less educated persons also encounter this phenomenon, possibly at different age ranges. Also, the definition of the rush hour needs further elaboration, and the perception of feeling rushed presumably varies due to personal traits and might be subjectively perceived in different ways. Nevertheless, the rush hour of life might be a new approach in life course analyses to study family formation in modern societies. 


\section{Appendix}

Table A1. Distribution of the variables in the base model (in percent)

\begin{tabular}{|c|c|c|c|c|c|c|}
\hline & \multicolumn{3}{|c|}{$\begin{array}{l}\text { Childless university } \\
\text { graduates }\end{array}$} & \multicolumn{3}{|c|}{$\begin{array}{c}\text { University graduates with one } \\
\text { child }\end{array}$} \\
\hline & All & Women & Men & All & Women & Men \\
\hline \multicolumn{7}{|l|}{ Age } \\
\hline $27-29$ & 32 & 34 & 29 & 11 & 12 & 8 \\
\hline $30-34$ & 44 & 44 & 44 & 47 & 45 & 50 \\
\hline $35-40$ & 24 & 22 & 27 & 43 & 43 & 42 \\
\hline \multicolumn{7}{|l|}{ Country } \\
\hline Germany & 11 & 10 & 14 & 19 & 23 & 13 \\
\hline Austria & 21 & 24 & 17 & 19 & 20 & 18 \\
\hline Austrian female researchers & 11 & 19 & 0 & 7 & 11 & 0 \\
\hline France & 26 & 23 & 29 & 28 & 28 & 29 \\
\hline Netherlands & 16 & 13 & 19 & 8 & 8 & 9 \\
\hline Norway & 15 & 12 & 21 & 18 & 11 & 31 \\
\hline \multicolumn{7}{|l|}{ Gender } \\
\hline Male & 41 & & & 35 & & \\
\hline Female & 59 & & & 65 & & \\
\hline \multicolumn{7}{|l|}{ Partner status } \\
\hline Married & 14 & 14 & 14 & 63 & 58 & 71 \\
\hline Cohabiting & 29 & 31 & 26 & 26 & 28 & 22 \\
\hline Living apart together & 24 & 24 & 24 & 5 & 5 & 4 \\
\hline No partner & 33 & 32 & 35 & 6 & 8 & 3 \\
\hline \multicolumn{7}{|l|}{ Relationship quality } \\
\hline (Very) good quality & 84 & 83 & 85 & 75 & 77 & 73 \\
\hline (Relatively) poor quality & 16 & 17 & 15 & 25 & 23 & 27 \\
\hline \multicolumn{7}{|l|}{ Employment status } \\
\hline Full time & 81 & 76 & 89 & 61 & 45 & 91 \\
\hline Part time & 10 & 15 & 4 & 21 & 30 & 4 \\
\hline Not employed & 8 & 9 & 7 & 18 & 24 & 5 \\
\hline $\mathrm{N}$ abs. (unweighted) & 1,072 & 633 & 439 & 397 & 260 & 137 \\
\hline
\end{tabular}

Source: GGS Wave 1. 
Table A2. Estimated coefficients from probit regressions for the desire to have a child within the next three years and sample distribution; basic model including all parities

\begin{tabular}{|c|c|c|c|c|c|c|}
\hline & \multicolumn{3}{|c|}{ Estimated coefficients } & \multicolumn{3}{|c|}{$\begin{array}{l}\text { Distribution of } \\
\text { variables }\end{array}$} \\
\hline & All & Women & Men & All & Women & Men \\
\hline Age & & & & & & \\
\hline $27-29$ & $-0.31 * * *$ & $-0.30 * *$ & $-0.36 * *$ & 18 & 19 & 17 \\
\hline $30-34^{\mathrm{a}}$ & 0 & 0 & 0 & 39 & 39 & 38 \\
\hline $35-40$ & $-0.49 * * *$ & $-0.63 * * *$ & $-0.34 * *$ & 43 & 42 & 45 \\
\hline Country & & & & & & \\
\hline Germany $^{\mathrm{a}}$ & 0 & 0 & 0 & 15 & 15 & 13 \\
\hline Austria & 0.13 & 0.05 & $0.29+$ & 18 & 20 & 16 \\
\hline Austrian female researchers & -0.14 & -0.11 & & 7 & 12 & 0 \\
\hline France & $0.30 * *$ & $0.33 *$ & $0.29+$ & 28 & 28 & 29 \\
\hline Netherlands & -0.16 & 0.09 & $-0.44 *$ & 12 & 10 & 15 \\
\hline Norway & 0.13 & $0.33 *$ & -0.03 & 20 & 15 & 27 \\
\hline Gender & & & & & & \\
\hline Male $^{\mathrm{a}}$ & 0 & & & 39 & & \\
\hline Female & -0.00 & & & 61 & & \\
\hline Parity & & & & & & \\
\hline 0 children $^{\mathrm{a}}$ & 0 & 0 & 0 & 49 & 47 & 52 \\
\hline 1 child & $-0.19 *$ & -0.15 & -0.25 & 18 & 19 & 16 \\
\hline 2 children & $-1.45 * * *$ & $-1.51 * * *$ & $-1.41 * * *$ & 24 & 24 & 24 \\
\hline 3 and more children & $-1.89 * * *$ & $-1.95 * * *$ & $-1.87 * * *$ & 9 & 9 & 8 \\
\hline Partner status & & & & & & \\
\hline Married & 0.12 & 0.12 & 0.12 & 45 & 44 & 45 \\
\hline Cohabiting $^{\mathrm{a}}$ & 0 & 0 & 0 & 23 & 24 & 22 \\
\hline Living apart together (LAT) & $-0.52 * * *$ & $-0.52 * * *$ & $-0.52 * *$ & 13 & 13 & 14 \\
\hline No partner & $-0.88 * * *$ & $-0.83 * * *$ & $-0.95 * * *$ & 19 & 18 & 19 \\
\hline Relationship quality & & & & & & \\
\hline (Very) good quality ${ }^{\mathrm{a}}$ & 0 & 0 & 0 & 78 & 77 & 79 \\
\hline $\begin{array}{l}\text { (Relatively) poor quality } \\
\text { Employment status }\end{array}$ & -0.12 & -0.10 & -0.14 & 22 & 23 & 21 \\
\hline Full time ${ }^{\text {a }}$ & 0 & 0 & 0 & 70 & 57 & 91 \\
\hline Part time & -0.09 & -0.04 & 0.03 & 17 & 25 & 4 \\
\hline Not employed & $0.28^{* *}$ & $0.36 * *$ & 0.31 & 13 & 18 & 5 \\
\hline Constant & $0.69 * * *$ & $0.66 * * *$ & $0.71 * * *$ & & & \\
\hline Pseudo $\mathrm{R}^{2}$ & 0.20 & 0.22 & 0.18 & & & \\
\hline $\mathrm{N}$ & 2,187 & 1,344 & 843 & 2,187 & 1,344 & 843 \\
\hline
\end{tabular}

Significance levels: $+\mathrm{p}<0.10 ; * \mathrm{p}<0.05 ; * * \mathrm{p}<0.01 ; * * * \mathrm{p}<0.001$.

${ }^{\text {a }}$ Reference category.

Source: GGS Wave 1. 
Table A3

Distribution of the variables in the expanded model (in percent)

\begin{tabular}{|c|c|c|c|c|c|c|}
\hline & \multicolumn{3}{|c|}{ Childless university graduates } & \multicolumn{3}{|c|}{$\begin{array}{l}\text { University graduates with } \\
\text { one child }\end{array}$} \\
\hline & All & Women & Men & All & Women & Men \\
\hline Age & & & & & & \\
\hline $27-29$ & 32 & 34 & 29 & 10 & 12 & 7 \\
\hline $30-34$ & 43 & 43 & 42 & 47 & 45 & 52 \\
\hline $35-40$ & 25 & 22 & 29 & 42 & 43 & 40 \\
\hline Country & & & & & & \\
\hline Germany & 13 & 11 & 17 & 20 & 24 & 14 \\
\hline Austria & 25 & 27 & 22 & 21 & 22 & 20 \\
\hline Austrian female academics & 13 & 22 & 0 & 8 & 12 & 0 \\
\hline France & 30 & 26 & 35 & 31 & 30 & 33 \\
\hline Norway & 19 & 14 & 26 & 20 & 12 & 34 \\
\hline Gender & & & & & & \\
\hline Male & 39 & & & 34 & & \\
\hline Female & 61 & & & 66 & & \\
\hline Partner status & & & & & & \\
\hline Married less than 3 years & 2 & 1 & 4 & 6 & 3 & 11 \\
\hline Married 3 years and longer & 12 & 12 & 11 & 56 & 55 & 59 \\
\hline $\begin{array}{l}\text { Cohabitating less than } 3 \\
\text { years }\end{array}$ & 12 & 13 & 0 & 0 & 0 & 10 \\
\hline Cohabitating 3 years and & 12 & 10 & 3 & 5 & 3 & 10 \\
\hline longer & 17 & 18 & 15 & 18 & 21 & 14 \\
\hline LAT less than 2 years & 12 & 12 & 13 & 3 & 3 & 1 \\
\hline LAT 2 years and longer & 12 & 12 & 13 & 1 & 2 & 1 \\
\hline No partner & 33 & 31 & 36 & 6 & 8 & 3 \\
\hline Relationship quality & & & & & & \\
\hline (Very) good quality & 82 & 81 & 83 & 73 & 75 & 70 \\
\hline (Relatively) poor quality & 18 & 19 & 17 & 27 & 25 & 30 \\
\hline Working hours & & & & & & \\
\hline Less than 30 hours & 8 & 9 & 5 & 15 & 22 & 2 \\
\hline 30-34 hours & 3 & 4 & 1 & 5 & 6 & 2 \\
\hline 35-40 hours & 39 & 42 & 35 & 35 & 32 & 40 \\
\hline $41-50$ hours & 31 & 26 & 39 & 21 & 11 & 41 \\
\hline More than 50 hours & 10 & 9 & 11 & 6 & 3 & 11 \\
\hline Not employed & 9 & 9 & 8 & 18 & 25 & 5 \\
\hline $\begin{array}{l}\text { Duration in the current } \\
\text { job }\end{array}$ & & & & & & \\
\hline Less than 1 year & 20 & 21 & 17 & 12 & 11 & 13 \\
\hline 1 year and longer & 71 & 69 & 74 & 70 & 64 & 82 \\
\hline Not employed & 9 & 9 & 8 & 18 & 25 & 5 \\
\hline $\mathrm{N}$ abs. (unweighted) & 889 & 540 & 349 & 355 & 233 & 122 \\
\hline
\end{tabular}

Source: GGS Wave 1. 
Table A4. Estimated coefficients from probit regressions for the desire to have a child within the next three years and sample distribution; expanded model including all parities

\begin{tabular}{|c|c|c|c|c|c|c|}
\hline & All & Women & Men & All & Women & Men \\
\hline Age & & & & & & \\
\hline $27-29$ & $-0.28 * *$ & $-0.32 * *$ & -0.24 & 18 & 19 & 16 \\
\hline $30-34^{\mathrm{a}}$ & 0 & 0 & 0 & 38 & 39 & 37 \\
\hline $35-40$ & $-0.51 * *$ & $-0.65 * * *$ & $-0.35^{* *}$ & 44 & 42 & 47 \\
\hline \multicolumn{7}{|l|}{ Country } \\
\hline Germany $^{\mathrm{a}}$ & 0 & 0 & 0 & 16 & 16 & 16 \\
\hline Austria & 0.13 & 0.06 & $0.32+$ & 21 & 23 & 19 \\
\hline Austrian female researchers & -0.12 & -0.10 & & 8 & 14 & 0 \\
\hline France & $0.30 * *$ & $0.36 * * *$ & $0.33 *$ & 32 & 31 & 33 \\
\hline Norway & 0.12 & $0.33 *$ & 0.03 & 23 & 17 & 32 \\
\hline \multicolumn{7}{|l|}{ Gender } \\
\hline Male $^{a}$ & 0 & & & 38 & & \\
\hline Female & -0.06 & & & 62 & & \\
\hline \multicolumn{7}{|l|}{ Parity } \\
\hline 0 children & 0 & 0 & 0 & 47 & 46 & 49 \\
\hline 1 child & $-0.28 * *$ & $-0.22+$ & $-0.42 *$ & 19 & 20 & 17 \\
\hline 2 children & -1.44 & $-1.47 * * *$ & $-1.51 * * *$ & 25 & 25 & 26 \\
\hline 3 and more children & $-1.97 * * *$ & $-2.04 * * *$ & $-2.04 * * *$ & 8 & 9 & 8 \\
\hline \multicolumn{7}{|l|}{ Partner status } \\
\hline Married less than 3 years & 0.57 & $\left(1.40^{*}\right)$ & 0.29 & 2 & 1 & 4 \\
\hline Married 3 years and longer & $0.19+$ & 0.13 & $0.31+$ & 43 & 44 & 43 \\
\hline Cohabiting less than 3 years & $0.29 *$ & 0.25 & 0.38 & 8 & 8 & 7 \\
\hline Cohabiting 3 years and & 0 & 0 & 0 & 16 & & \\
\hline longer & & & & & 16 & 14 \\
\hline LAT less than 2 years & $-0.56 * * *$ & $-0.56 * *$ & $-0.53^{*}$ & 7 & 6 & 7 \\
\hline LAT 2 years and longer & $-0.39 *$ & $-0.40^{*}$ & -0.31 & 6 & 6 & 7 \\
\hline No partner ${ }^{\mathrm{a}}$ & $-0.81 * * *$ & $-0.75 * * *$ & $-0.87 * * *$ & 18 & 18 & 19 \\
\hline \multicolumn{7}{|l|}{ Partner quality } \\
\hline (Relatively) poor quality & -0.13 & -0.11 & -0.13 & 75 & 74 & 76 \\
\hline (Very) good quality ${ }^{\mathrm{a}}$ & 0 & 0 & 0 & 25 & 26 & 24 \\
\hline \multicolumn{6}{|l|}{ Working hours } & \\
\hline $30-34$ hours & 0.03 & 0.11 & -0.38 & 5 & 6 & 2 \\
\hline $35-40$ hours $^{\text {a }}$ & 0 & 0 & 0 & 36 & 36 & 37 \\
\hline 41-50 hours & -0.01 & 0.02 & -0.06 & 26 & 17 & 40 \\
\hline More than 50 hours & -0.13 & $-0.42 *$ & 0.05 & 8 & 6 & 12 \\
\hline Not employed & $0.23 *$ & $0.37 * *$ & 0.13 & 14 & 19 & 5 \\
\hline \multicolumn{7}{|l|}{ Duration of current job } \\
\hline Less than 1 year & -0.16 & -0.02 & $-0.32+$ & 15 & 15 & 15 \\
\hline $1-3$ years & -0.03 & 0.01 & -0.00 & 72 & 67 & 80 \\
\hline 4 years and longer ${ }^{a}$ & 0 & 0 & 0 & 14 & 19 & 5 \\
\hline Constant & $0.75 * * *$ & $0.65 * * *$ & $0.69 * *$ & & & \\
\hline Pseudo $\mathrm{R}^{2}$ & 0.21 & 0.23 & 0.20 & & & \\
\hline $\mathrm{N}$ & 1,872 & 1,168 & 704 & 1,879 & 1,172 & 707 \\
\hline
\end{tabular}

Significance levels: $+\mathrm{p}<0.10 ; * \mathrm{p}<0.05 ; * * \mathrm{p}<0.01 ; * * * \mathrm{p}<0.001$.

${ }^{a}$ Reference category.

Remark: Numbers in parentheses indicate small size of subcategory (i.e. 1-2 percent).

Source: GGS Wave 1 


\section{References}

Auferkorte-Michaelis, N., Metz-Göckel, S., Wergen, J., \& Klein, A. (2006). Junge Elternschaft und Wissenschaftskarriere. Wie kinderfreundlich sind Wissenschaft und Universitäten? Zeitschrift für Frauenforschung und Geschlechterstudien, 23(4), $14-23$.

Bertram, H. (2007). Keine Zeit für Liebe: Die Rushhour des Lebens. In L. Mohn \& U. v. d. Leyen (Eds.), Familie gewinnt. Die Allianz und ihre Wirkungen für Unternehmen und Gesellschaft (pp. 32-47). Gütersloh: Verlag Bertelsmann Stiftung.

Bertram, H., \& Bujard, M. (2012). Zur Zukunft der Familienpolitik. In H. Bertram \& M. Bujar (Eds.), Zeit, Geld, Infrastruktur - zur Zukunft der Familienpolitik. Sonderband 19 Soziale Welt (pp. 3-24). Baden-Baden: Nomos.

Bertram, H., Bujard, M., \& Rösler, W. (2011). Rush-Hour des Lebens. Geburtenaufschub, Einkommensverläufe und familienpolitische Perspektiven. Journal für Reproduktivmedizin und Endokrinologie, 8(2), 91-99.

Bittman, M., \& Wajcman, J. (2000). The rush hour: character of leisure time and gender equity. Social Forces, 79, 165-190.

BMBF. (2010). Kinder - Wunsch und Wirklichkeit in der Wissenschaft. Bonn, Berlin.

BMFSFJ. (2006). Familie zwischen Fleibilität und Verlässlichkeit. Perspektiven für eine lebenslaufbezogene Familienpolitik. Siebter Familienbericht. Berlin.

Bongaarts, J., \& Sobotka, T. (2011). Demographic explanation for the recet rise in European fertility: Analysis based on the tempo and parity-adjusted total fertility. European Demographic Research Papers 4, Vienna: Vienna Institute of Demography of the Austrian Academy of Sciences.

Bovenberg, A. L. (2008). The life-course perspective and social policies: An overview of the issues. CESifo Economic Studies, 55, 593-641. doi: 10.1093/cesifo/ifn029

Buber, I. (2010). Wissenschaftlerinnen in Österreich - Zusatzerhebung im Rahmen des GGS. Dokumentation der Datenerhebung und deskriptive Ergebnisse. VID Working Paper 2/2010, Vienna: Vienna Institute of Demography.

Buber, I., Berghammer, C., \& Prskawetz, A. (2011). Doing science forgoing children. VID Working Paper 1/2011, Vienna: Vienna Institute of Demography.

Buchholz, L. (2004). Wissenschaftskarrieren an österreichischen Universitäten. Erfahrungen und Einstellungen von Professorinnen und Professoren. In E. Appelt (Ed.), Karriereschere. Geschlechterverhältnisse im österreichischen Wissenschaftsbetrieb (pp. 71-91). Vienna: LIT.

Bulatao, R. A. (1981). Values and disvalues of children in successive childbearing decisions. Demography, 18(1), 1-25.

Davie, E., \& Mazuy, M. (2010). Women's fertility and educational level in France. Evidence from the Annual Census Surveys. Population-E, 65(3), 415-450.

Dommermuth, L., Klobas, J., \& Lappegard, T. (2011). Now or later? The Theory of Planned Behavior and timing of fertility intentions. Advances in Life Course Research, 16(1), 42-53. doi: 10.1016/j.alcr.2011.01.002

Dorbritz, J. (2005). Kinderlosigkeit in Deutschland und Europa - Daten, Trends und Einstellungen. Zeitschrift für Bevölkerungswissenschaft, 30(4), 359-408.

Dorbritz, J. (2011). Dimensionen der Kinderlosigkeit in Deutschland. Bevölkerungsforschung. Mitteilungen aus dem Bundesinstitut für Bevölkerungsforschung, 32, 2-6. 
Duschek, K.-J., \& Wirth, H. (2005). Kinderlosigkeit von Frauen im Spiegel des Mikrozensus. Eine Kohortenanalyse der Mikrozensen 1987 bis 2004. Wirtschaft und Statistik, 8, 800-820.

Dykstra, P. A., Kalmijn, M., Knijn, T. C. M., Komter, A. E., Liefbroer, A. C., \& Mulder, C. H. (2005). Codebook of the Netherlands Kinship Panel Study, a multi-actor, multi-method panel study on solidarity in family relationships, Wave 1 NKPS Working Paper No. 4. The Hague: Netherlands Interdisciplinary Demographic Institute.

Elder, G. H. (1977). Family history and the life course. Journal of Family History, 2(4), 279-304. doi: 10.1177/036319907700200402

Esping-Anderson, G. (1990). The three worlds of welfare capitalism. New Jersey: Princeton University Press.

Fagnani, J. (2002). Why do French women have more children than German women? Family policies and attitudes towards child care outside the home. Community, Work \& Family, 5(1), 103-119. doi: 1080/1366880022010218

Fokkema, T., Valk, H. d., Beer, J. d., \& Duin, C. v. (2008). The Netherlands: Childbearing within the context of a "Poldermodel" society. Demographic Research, 19(21), 743794.

Frejka, T. (2008). Parity distribution and completed family size in Europe: Incipient decline of the two-child family model? Demographic Research, 19(4), 47-72. doi: 10.4054/DemRes.2008.10.4

Frejka, T., \& Sardon, J.-P. (2004). Childbearing trends and prospects in low-fertility countries. A cohort analysis. Dordrecht, Boston, London: Kluwer Academic Publishers.

Gauthier, A. H. (1996). The state and the family: a comparative analysis of family policies in industrialized countries. Oxford: Clarendon Press.

Gerlach, I. (2004). Familienpolitik. Wiesbaden: VS.

Goldstein, J., \& Kreyenfeld, M. (2011). Has East Germany overtaken West Germany? Recent trends in order-specific fertility. Population and Development Review, 37(3), 453-472. doi: 10.1111/j.1728-4457.2011.00430.x

Goldstein, J., Kreyenfeld, M., Huinink, J., Konietzka, D., \& Trappe, H. (2010). Familie und Partnerschaft in Ost- und Westdeutschland. Ergebnisse im Rahmen des Projektes „Demographic Differences in Life Course Dynamics in Eastern and Western Germany". Rostock: Max Planck Institute for Demographic Research

Hamermesh, D. S., \& Lee, J. (2007). Stressed out on four continents: Time crunch or yuppie kvetch? The Review of Economics and Statistics, 889(2), 374-383.

Hochschild, A. R. (1997). The time bind: When work becomes home and home becomes work. New York: Metropolitan Books.

Jansen, M. D., \& Liefbroer, A. C. (2006). Couple's attitudes, childbirth, and the division of labour. Journal of Family Issues, 27(11), 1487-1511.

Keizer, R. (2010). Remaining childless. Causes and consequences from a life course persepctive. Dissertation, Utrecht University, Utrecht.

Keizer, R., Dykstra, P. A., \& Jansen, M. D. (2008). Pathways into childlessness: Evidence of gendered life course dynamics. Journal of Biosocial Science, 40, 863-878. doi: $10.1017 / \mathrm{S} 0021932007002660$

Klammer, U. (2010). The "Rush Hour" of Life: Insecurities and strains in early life phase as challenge for a life course-oriented, sustainable policy. In J. C. Tremmel (Ed.), A young generation under pressure? The financial situation and the "rush hour" of the 
cohorts 1970-1985 in a generational comparison (pp. 155-166). Heidelberg: Springer.

Konietzka, D., \& Kreyenfeld, M. (Eds.). (2007). Ein Leben ohne Kinder. Kinderlosigkeit in Deutschland. Wiesbaden: VS.

Köppen, K., Mazuy, M., \& Toulemon, L. (2007). Kinderlosigkeit in Frankreich. In D. Konietzka \& M. Kreyenfeld (Eds.), Ein Leben ohne Kinder. Kinderlosigkeit in Deutschland (pp. 83-105). Wiesbaden: VS.

Kravdal, O. (2001). The high fertility of college educated women in Norway: An artefact of the separate modelling of each parity transition. Demographic Research, 5(6), $188-216$.

Kravdal, O., \& Rindfuss, R. R. (2008). Changing Relationships between Education and Fertility: A Study of Women and Men Born 1940 to 1964. American Sociological Review, 73, 854-873. doi: 10.1177/000312240807300508

Kreyenfeld, M. (2008). Ökonomische Unsicherheit und der Aufschub der Familiengründung. In M. Szydlik (Ed.), Flexibilisierung. Folgen für Arbeit und Familie (pp. 232-255). Wiesbaden: VS.

Kreyenfeld, M. (2010). Uncertainties in female employment careers and the postponement of parenthood in Germany. European Sociological Review, 26(3), 351-366. doi: 10.1093/esr/jcp026

Kreyenfeld, M., \& Konietzka, D. (2007). Die Analyse von Kinderlosigkeit in Deutschland: Dimensionen - Daten - Probleme. In D. Koniettzka \& M. Kreyenfeld (Eds.), Ein Leben ohne Kinder. Kinderlosigkeit in Deutschland (pp. 11-41). Wiesbaden: VS.

Kreyenfeld, M., Scholz, R., Peters, F., \& Wlosnewski, I. (2010). Order-specific fertility rates for Germany. Estimates from perinatal statistics for the period 2001-2008. Comparative Population Studies/ Zeitschrift für Bevölkerungswissenschaft, 35(2), 207-224.

Kreyenfeld, M., Zeman, K., Burkimsher, M., \& Jaschinski, I. (2011). Fertility data for German-speaking countries: What is the potential? Where are the pitfalls? Comparative Population Studies/ Zeitschrift für Bevölkerungswissenschaft, 36(23), 349-380. doi: 10.4232/10.CPoS-2011-06en

Lappegard, T. (2000). New fertility trend in Norway. Demographic Research, 2(3), 1-23.

Lappegard, T. (2002). Education attainment and fertility pattern among Norwegian women. Document 2002/18, Department of Social Ststistics, Statistics Norway, Oslo, from http://www.ssb.no/emner/02/02/10/doc_200218/doc_200218.pdf

Lesthaeghe, R., \& Surkyn, J. (1988). Cultural dynamics and the economic theories of fertility change. Population and Development Review, 14(1), 1-45.

Liefbroer, A. C. (2005). The impact of perceived costs and rewards of childbearing on entry into motherhood: evidence from a panel study. European Journal of Population, 21, 367-391.

Liefbroer, A. C., \& Corijn, M. (1999). Who, what, where, and when? Specifying the impact of educational attainment and labour force participation on family formation. European Journal of Population, 15(1), 45-75.

Lind, I. (2008). Balancing career and family in higher education - new trends and results. In S. Grenz, B. Kortendiek, M. Kriszio \& A. Löther (Eds.), Gender equality programmes in higher education (pp. 193-208). Berlin: VS Verlag Sozialwissenschaften.

Lothaller, H. (2008). Die 'rush hour' des Lebens und die Bedeutung der Familienarbeit und ihrer Aufteilung. Journal für Generationengerechtigkeit, 8(3), 4-8. 
Mayer, K. U. (1990). Lebensverläufe und sozialer Wandel (Sonderheft 31 der Kölner Zeitschrift für

Soziologie und Sozialpsychologie). Opladen: Westdeutscher Verlag.

Mayer, K. U. (2001). The paradox of global change and national path dependencies: Life course patterns in advanced societies. In A. E. Woodward \& M. Kohli (Eds.), Inclusions and exclusions in European societies (pp. 89-110). London: Routledge.

Mayer, K. U. (2003). The sociology of the life course and life span psychology - diverging or converging pathways? In U. M. Staudinger \& U. Lindenberger (Eds.), Understanding human development: Lifespan psychology in exchange with other disciplines. Dordrecht: Kluwer Academic Publisher.

Merz, E.-M., \& Liefbroer, A. C. (2011). Cross-national differences in the effect of educational attainment on fertility quantum: A study based on ESS data. Deliverable of the REPRO-project, from http://www.oeaw.ac.at/vid/repro/assets/docs/Merz-Liefbroer_quantum-fertility.pdf

Metz-Göckel, S. (2009). Wissenschaftlicher Nachwuchs ohne Nachwuchs? Zwischenergebnisse des Projekts "Wissen- oder Elternschaft? Kinderlosigkeit und Beschäftigungsverhältnisse an Hochschulen in Deutschland". Technische Universität Dortmund: Hochschuldidaktisches Zentrum.

Miller, W. B., \& Pasta, D. (1995). Behavioral intentions: Which ones predict fertility behavior in married couples? Journal of Applied Social Psychology, 25(6), 530555.

Ní Bhrolcháin, M., \& Beaujouan, E. (2012). Fertility postponement is largely due to rising educational enrolment. Population Studies, iFirst. doi: 10.1080/00324728.2012.697569

Nimwegen, N. v., Esveldt, I., \& Beets, G. (2003). Population trends and family policies in the Netherlands. Journal of Population and Social Security (Population), Supplement to Volume 1, 203-229.

Peuckert, R. (2008). Familienformen im sozialen Wandel. Wiesbaden: VS.

Plantenga, J., \& Remery, C. (2009). The provision of childcare services. A comparative review of 30 European countries. Luxembourg: Publications Office of the European Union.

Prskawetz, A., Sobotka, T., Buber, I., Engelhardt, H., \& Gisser, R. (2008). Austria: Persistent low fertility since the mid-1980s. Demographic Research, 19(12), 293360.

Rønsen, M. (2004). Fertility and family policy in Norway - A reflection on trends and possible connections. Demographic Research, 10(10), 263-286.

Sauer, L., Ruckdeschel, K., \& Naderi, R. (2012). Reliability of retrospective event histories within the German Generations and Gender Survey. BIB Working Paper 1/2012: Wiesbaden: Federal Institute for Population Research.

Scharein, M., \& Unger, R. (2005). Kinderlosigkeit bei Akademikerinnen? Die Aussagekraft empirischer Daten zur Kinderlosigkeit bei Akademikerinnen. BIBMitteilungen, 26, 6-13.

Schneider, N., Limmer, R., \& Ruckdeschel, K. (2002). Mobil, flexibel, gebunden. Frankfurt/Main: Campus.

Schoen, R., Astone, N. M., Kim, Y. J., Nathanson, C., \& Fields, J. M. (1999). Do fertility intentions affect fertility behavior? Journal of Marriage and the Family, 61(3), 790799. 
Skirbekk, V. (2008). Fertility trends by social status. Demographic Research, 18(5), 145180.

Sobotka, T. (2005). Childless societies? Trends and projections of childlessness in Europe and the United States. Paper presented at the 2005 PAA Meeting Philadelphia.

Sobotka, T. (2010). Shifting parenthood to advanced reproductive ages: Trends, causes and consequences. In J. C. Tremmel (Ed.), A young generation under pressure? The financial situation and the "rush hour" of the cohorts 1970-1985 in a generational comparison (pp. 12-154). Berlin-Heidelberg: Springer.

Sobotka, T. (2011). Fertility in Austria, Germany, and Switzerland: Is there a common pattern? Comparative Population Studies/ Zeitschrift für Bevölkerungswissenschaft, 36(2-3), 263-304. doi: 10.4232/10.CPoS-2011-11en

Sobotka, T., \& Lutz, W. (2011). Misleading policy messages derived from the period TFR: Should we stop using it? Comparative Population Studies/ Zeitschrift für Bevölkerungswissenschaft, 35(3), 637-664.

Spéder, Z., \& Kapitány, B. (2009). How are time-dependent childbearing intentions realized? Realization, postponement, abandonment, bringing forward / Les intentions de fécondité sont-elles réalisées dans le délai prévu? Réalisation, report, abandon, advancement. European Journal of Population / Revue Européenne de Démographie 25(4), 503-523.

Statistisches Bundesamt. (2010). Mikrozensus 2008 ---Neue Daten zur Kinderlosigkeit. Ergänzende Tabellen zur Pressekonferenz am 29. Juli 2009 in Berlin. Überarbeitete und erweiterte Version. Wiesbaden: Statistisches Bundesamt.

Testa, M. R. (2012). Couple disagreement about short-term fertility desires in Austria: Effects on intentions and contraceptive behaviour. Demographic Research, 26(3), 63-98. doi: 10.4054/DemRes.2012.26.3

Testa, M. R., Cavalli, L., \& Rosina, A. (2012). The decision of whether to have a child: Does couple disagreement matter? VID Working Paper 7/2012, Vienna: Vienna Institute of Demography.

Thomson, E., \& Hoem, J. M. (1998). Couple childbearing plans and births in Sweden. Demography, 35(3), 315-322.

Toulemon, L., Pailhé, A., \& Rossier, C. (2008). France: high and stable fertility. Demographic Research, 19(16), 503-556.

Trappe, H., \& Rosenfeld, R. A. (2000). How do children matter? A comparison of gender earnings inequality for young adults in the former East Germany and the former West Germany. Journal of Marriage and the Family, 62, 489-507.

VID-IIASA. (2012). European demographic data sheet 2012: Vienna Institute of Demography (VID), International Institute for Applied System Analyses (IIASA), and Population Reference Bureau (PRB).

Vikat, A., Spéder, Z., Beets, G., Billari, F., Bühler, C., Désesquelles, A., et al. (2007). Generations and Gender Survey: Concept and Design. New York and Geneva: United Nations Publication.

Widmer, E. D., \& Ritschard, G. (2009). The de-standardization of the life course: Are men and women equal? Advances in Life Course Research 14(1-2), 28-39. doi: 10.1016/j.alcr.2009.04.001

Yamaguchi, K., \& Ferguson, L. R. (1995). The stopping and spacing of childbirths and their birth-history predictors: rational-choice theory and event-history analysis. American Sociological Review, 60(2), 272-298. 


\section{VIENNA INSTITUTE OF DEMOGRAPHY}

\section{Working Papers}

Testa, Maria Rita, Laura Cavalli, and Alessandro Rosina, The Decision of Whether to Have a Child: Does Couple Disagreement Matter?, VID Working Paper 07/2012.

Kuhn, Michael and Klaus Prettner, Growth and Welfare Effects of Health Care in Knowledge Based Economies, VID Working Paper 06/2012.

Sander, Nikola and Martin Bell, Age, Period and Cohort Effects on Migration of the Baby Boomers in Australia, VID Working Paper 05/2012.

Grafeneder-Weissteiner, Theresa, Ingrid Kubin, Klaus Prettner, Alexia Prskawetz, and Stefan Wrzaczek, Coping with Inefficiencies in a New Economic Geography Model, VID Working Paper 04/2012.

Goujon, Anne, Éric Caron Malenfant, and Vegard Skirbekk, Towards a Catholic North America? Projections of Religion in Canada and the US beyond the Mid-21st Century, VID Working Paper 03/2012.

Di Giulio, Paola, Christoph Bühler, Andreas Ette, Romina Fraboni, and Kerstin Ruckdeschel, Social Capital and Fertility Intentions: The Case of Italy, Bulgaria, and West Germany, VID Working Paper 02/2012.

Abel, Guy J., Estimating Global Migration Flow Tables Using Place of Birth Data, VID Working Paper 01/2012.

Ediev, Dalkhat M., At Modal Age at Death, the Hazard Rate is Determined by its Derivative, VID Working Paper 08/2011.

Zeman, Kryštof, Tomáš Sobotka, Richard Gisser, Maria Winkler-Dworak, and Wolfgang Lutz, Geburtenbarometer Vienna: Analysing Fertility Convergence between Vienna and Austria, VID Working Paper 07/2011 (English and German versions available).

Feichtinger Gustav, Michael Kuhn, Alexia Prskawetz, and Stefan Wrzaczek, The Reproductive Value as Part of the Shadow Price of Population, VID Working Paper 06/2011.

Barakat, Bilal, Time is Money: Could Deferred Graduate Retirement Finance Higher Education?, VID Working Paper 05/2011.

The Vienna Institute of Demography Working Paper Series receives only limited review. Views or opinions expressed herein are entirely those of the authors. 